\title{
Native and non-indigenous boring polychaetes in Chile: a threat to native and commercial mollusc species
}

\author{
Poliquetos perforadores nativos y no indígenas en Chile: \\ una amenaza para moluscos nativos y comerciales
}

RODRIGO A. MORENO*, PAULA E. NEILL \& NICOLÁS ROZBACZYLO

\begin{abstract}
Departamento de Ecología and Center for Advanced Studies in Ecology \& Biodiversity (CASEB), Facultad de Ciencias Biológicas, Pontificia Universidad Católica de Chile, Casilla 114-D, Santiago 6513677, Chile;

* e-mail for corresponding author: romoren@bio.puc.cl
\end{abstract}

\begin{abstract}
Boring polychaetes infesting the shells of aquacultured molluscs affect host fitness and cause serious economic problems for the aquaculture industry. In Chile, knowledge of the native and non-indigenous polychaete fauna associated with mollusc hosts is limited, in spite of the fact that numerous native and nonindigenous mollusc species are actively harvested. We present the first complete list of boring polychaete species present in Chile, with a review of the information regarding each species' status as a native or nonindigenous species (NIS), together with information on native and introduced ranges, affected host species, likely vectors of introduction and donor areas. We recorded a total of nine boring polychaetes present along the Chilean coast including native and NIS. Within the NIS category we provide the first published report of the Sabellid Terebrasabella heterouncinata in South America. Boring polychaetes utilized both native and introduced host species. The finding of polychaete species which utilized multiple native and NIS hosts, indicates a potential risk for spread between aquaculture facilities and the natural environment. Our analysis suggests that aquaculture activities are probably the primary introduction vector for boring polychaete species to Chile and that this region does not differ in the magnitude of introduced boring polychaetes relative to other regions of the world. We discuss current laws and management regarding polychaete infestations and make recommendations for future management in Chile, which should contemplate a rational compromise between the socio-economic needs of the country and plans to protect and preserve the nation's biodiversity.
\end{abstract}

Key words: Bioinvasions, legislation, management, NIS, Southeastern Pacific.

\section{RESUMEN}

La colonización de especies de poliquetos perforadores sobre conchas de moluscos de cultivos puede afectar la adecuación biológica del hospedador y causar serios problemas económicos para la industria acuícola. En Chile, el conocimiento de la fauna de poliquetos perforadores nativos y no indígenas asociados con moluscos hospedadores es limitado, a pesar del gran número de moluscos nativos y no indígenas que son activamente cultivados. Se presenta el primer listado completo de poliquetos perforadores en Chile, con información sobre el estatus de cada especie como nativa o especie no indígena (ENI), rangos nativos e introducidos, las especies hospedadores afectadas, los probables vectores de introducción y áreas donantes. Se registró un total de nueve especies de poliquetos perforadores en Chile, incluyendo especies nativas y ENI. Dentro de la categoría ENI se registra por primera vez a Terebrasabella heterouncinata en Sudamérica. Los poliquetos perforadores infestan especies nativas e introducidas. El hallazgo de poliquetos que utilizan múltiples hospedadores nativos y ENI, indica un potencial riesgo de diseminación entre centros de cultivos y el ambiente natural. Nuestro análisis sugiere que las actividades acuícolas son probablemente el principal vector de introducción de especies de poliquetos perforadores en Chile, no difiriendo en orden de magnitud con respecto a otras regiones del mundo. Se discute la actual legislación y planes de manejo sobre infestaciones de poliquetos perforadores y se realizan recomendaciones para el futuro manejo en Chile, la que debería contemplar un compromiso racional entre las necesidades socioeconómicas del país y planes de protección y preservación de la biodiversidad de la nación.

Palabras clave: Bioinvasiones, legislación, manejo, ENI, Pacífico suroriental. 


\section{INTRODUCTION}

Aquacultured organisms are frequently fouled by a diverse array of epibionts, including algae, sponges, bryozoans, barnacles, molluscs, ascidians and polychaetes (e.g. Corriero \& Pronzato 1987, Martin \& Britayev 1998, López et al. 2000, Giacobbe 2002, Castilla et al. 2005). When marine species are introduced to new areas-often for aquaculture purposes-their associated epibionts can also be accidentally introduced (Naylor et al. 2001). This phenomenon presents a risk to the biodiversity of the recipient communities through species interactions between the non-indigenous assemblage and the recipient community (e.g. Naylor et al. 2001). For example, the non-indigenous epibionts may acquire new hosts in the recipient communities (e.g. Kuris and Culver 1999, Culver \& Kuris 2004) or, conversely, organisms from the recipient community may learn to consume or otherwise utilize the introduced species (e.g. Magoulick \& Lewis 2002). Either of these scenarios could lead to changes in population dynamics and community structure (e.g. Grosholz et al. 2000, Ross et al. 2003).

Boring polychaetes frequently infest the shells of aquacultured mollusc species. These polychaetes can cause severe damage to the mollusc shells, affecting the fitness of their hosts (Blake \& Evans 1973, Handley \& Berquist 1997, Cáceres-Martínez et al. 1998, Martin \& Britayev 1998, Read 2004, McDiarmid et al. 2004) and often causing financial loss to aquaculturists. At least three families of boring polychaetes have been reported in the literature: Spionidae, Sabellidae and Cirratulidae. In particular, boring polychaetes of the spionid genera such as Boccardia, Dipolydora, Polydora and the sabellid Terebrasabella heterouncinata Fitzhugh and Rouse cause serious economic problems for the aquaculture industry at a global level (see Evans 1969, Kuris \& Culver 1999, Lleonart et al. 2003a, 2003b, Cárdenas \& Cañete 2004, Read 2004, Radashevsky \& Olivares 2005). The specific effects of boring polychaete species on their hosts have been well-studied for several commercially important molluscs both in their native and introduced ranges (e.g. oysters, scallops, mussels, abalone; Kent 1979, Basilio et al. 1995, Cáceres-Martínez et al. 1998, Kuris \&
Culver 1999, McDiarmid et al. 2004, Vargas et al. 2005), however there are few available studies of boring polychaetes on species that are not of economic importance.

In Chile, information regarding infestations of native and non-indigenous boring polychaetes on native and exotic molluscs of commercial importance is available, particularly for Spionidae polychaetes (see Rozbaczylo et al. 1980, Rozbaczylo et al. 1994, Basilio et al. 1995, Sato-Okoshi \& Takatsuka 2001, Cárdenas \& Cañete 2004, Radashevsky \& Olivares 2005, Bertrán et al. 2005) and Cirratulidae polychaetes of the genus Dodecaceria (see Carrasco 1977, Rozbaczylo \& Carrasco 1996). Nevertheless, Chile continues to lag behind other countries (e.g. Australia, New Zealand, USA) in the development of plans to prevent and manage polychaete invasions both to aquaculture facilities and natural environments. As Chile becomes an important global provider of several non-indigenous aquaculture products (e.g. salmon, abalone) it is vital to begin risk assessment and to implement appropriate management strategies to protect natural ecosystems while continuing to look after the socioeconomic interests of the country.

The purpose of this work is twofold: (1) to provide the most current listing of marine boring polychaete species present in Chile, reviewing information regarding each species' status as a native or non-indigenous species, together with information on native and introduced ranges, affected host species, and likely vectors of introduction and donor areas and (2) to discuss current laws and management regarding polychaete infestations and make recommendations for future management in Chile.

\section{Database and selection criteria}

The database compiled for this study consists in an exhaustive bibliographic review of boring polychaete species on calcareous substrates recorded along the Chilean coast, from the northern geopolitical boundary in Arica (18 ${ }^{\circ} 20^{\prime}$ S) to the southern tip of the continent at Cape Horn $\left(56^{\circ} \mathrm{S}\right)$. We reviewed the list of polychaetes of Chile compiled by Rozbaczylo (1985; and posterior publications) and technical reports from aquaculture facilities; in addition 
we conducted personal interviews with marine biologists, and experts in aquaculture and biosecurity from governmental and private entities $^{1}$ (see Appendices I and II). Using these sources we compiled a list of all of the boring polychaete species recorded in Chile. We categorized each of the selected species according to its geographic distribution as: (1) Native species (i.e. species with an historic range of distribution in Chile or $\mathrm{Peru}^{2}$ and (2) Non-indigenous species (NIS; i.e. species with a recent record in Chile, present outside of their native or historic range of distribution or their natural range of dispersal ${ }^{3}$; such species typically present a notorious, biogeographically incongruous range of distribution). For a marine boring polychaete to be included in the NIS category it had to conform to at least one of the following operational criteria based on Orensanz et al. (2002) and Castilla et al. (2005): (1) species whose non-native status in Chile was well-documented in scientific publications, written governmental reports, and/or based on the professional experience of the authors; (2) species with a notorious, incongruent range of distribution, including a single report or discontinuous range within Chile, (3) species with an extremely wide geographical distribution, including cosmopolitan species, (4) species documented as NIS in other regions, (5) species that were abundant in the vicinity of presumed centers of introductions (e.g. ports, aquaculture facilities), but rare or absent from other studied areas.

\footnotetext{
1 Given current controversy regarding legislation restricting aquaculture activities we are not able to provide the names of the experts that we interviewed in our published work. Instead we have provided the name of the researcher who conducted the interview. Additional information regarding specific interview questions and the professional profile of the experts we interviewed are available in Appendices I and II.

${ }^{2}$ We included the coast of Peru in our definition so as no to increase the number of NIS on the list by adhering to strict political boundaries. Therefore, if a species has an historic range in Peru as well as reports in Chile we have reported it as native to Chile. Note that using this broader geographic range may result in the inclusion of species that have undergone southward range extensions to Chile (such as those associated with ENSO phenomena).

${ }^{3}$ For this database we considered NIS to be those boring polychaete species present beyond the southeastern Pacific coasts of Chile or Peru, with a "recent" record in Chile; there was generally additional evidence of the non-native status of such species, such as a lack of records in the early literature or reported association with an introduced aquaculture species.
}

In Appendix III we provide a detailed identification of the three new records of boring polychaetes species recorded in this study. The identification of these species was made following keys by Gravier (1908), Fauchald (1977), Rozbaczylo (1980) and Fitzhugh \& Rouse (1999). We used a stereomicroscope and a scanning microscope to examine the diagnostic characters for each species. In addition, we compiled a list of the host species in Chile affected by each of the boring polychaete species in the database, with information on the status of each host as Native or Non-Indigenous to the Chilean coast and whether or not the host species is of economic importance. Finally, for each of the nonindigenous polychaete species we compiled information on their native and introduced ranges, and utilized this information, together with data on affected host species, to propose potential vectors and pathways of introduction to Chile. While precise introduction vectors and pathways are not known with certainty, we utilize indirect evidence (i.e. published reports of pathways used by congeneric or biologically similar species introduced to other marine systems around the world) or direct evidence of the presence of marine NIS utilizing specific vectors in Chile (e.g. specimens present on the shells of introduced mollusc species) following Castilla and Neill (in press).

\section{MARINE BORING POLYCHAETES IN CHILE}

\section{Current knowledge of boring polychaetes in Chile}

This is the first complete review of native and non-indigenous boring polychaetes present on the southeastern Pacific coast of Chile, together with information on the affected hosts and the possible vectors and donor areas of NIS polychaetes to the Chilean coast. We recorded a total of nine boring polychaete species present along the Chilean coast, belonging to the families Spionidae, Cirratulidae and Sabellidae. Three of these species were classified as native species (Table 1) and six species were classified as NIS (Tables 1 and 2). The geographical distributions of boring polychaete species recorded on the Chilean coast are presented in Table 3. Within the NIS 
category we emphasize the first published report of the sabellid fan worm, Terebrasabella heterouncinata in South America, which corresponds to specimens found infesting Haliotis rufescens in an abalone aquaculture facility of southern Chile (R.A. Moreno, personal interview).
Chile exhibits the same order of magnitude of introduced boring polychaetes relative to other regions of the world: 12 NIS polychaetes in New Zealand (see Cranfield et al. 1998, Handley 2000, Read 2004); seven in California, USA (see Blake and Evans 1973, Boyd et al. 2002); and seven in Australia (see McEnnulty

TABLE 1

List of boring polychaete taxa recorded on the Chilean coast, with information on the status of each polychaete as Native or Non-Indigenous species (NIS). In addition we list the host species that are affected by each boring polychaete, and we indicate whether affected hosts are Native or NonIndigenous species in Chile, and whether the host is of direct economic importance (\$)

Lista de taxa de poliquetos perforadores registrados en la costa del Pacífico suroriental de Chile, con información sobre el estatus de cada especie de poliqueto como Nativo o No indígena. Además se incluye una lista de las especies hospedadoras afectadas por cada poliqueto perforador, y se indica el estatus de los hospedadores como especies Nativas o No indígenas en Chile, y su importancia económica (\$)

\begin{tabular}{|c|c|c|c|c|}
\hline Boring polychaete species & Polychaete status & Affected host species & Host status & Source \\
\hline $\begin{array}{l}\text { Dipolydora huelma } \\
\text { Sato-Okoshi }\end{array}$ & \multirow[t]{3}{*}{ Native } & Crepidula sp. & Native & 1 \\
\hline \& Takatsuka, 2001 & & Haliotis rufescens & NIS, \$ & 2 \\
\hline \multirow{4}{*}{$\begin{array}{l}\text { Dodecaceria } \\
\text { choromyticola } \\
\text { Carrasco, } 1977\end{array}$} & & & & \\
\hline & \multirow[t]{3}{*}{ Native } & Choromytilus chorus & Native*,\$ & 3 \\
\hline & & Fissurella maxima & Native, \$ & 4 \\
\hline & & Aulacomya ater & Native, $\$$ & 4 \\
\hline \multirow{4}{*}{$\begin{array}{l}\text { Dodecaceria } \text { cf. } \\
\text { opulens Gravier, } 1908\end{array}$} & \multirow[t]{4}{*}{ Native } & Austromegabalanus psittacus & Native, $\$$ & 5 \\
\hline & & Concholepas concholepas & Native, \$ & 4 \\
\hline & & Haliotis rufescens & NIS, \$ & This study \\
\hline & & Balanus flosculus & Native & 6 \\
\hline \multirow{5}{*}{$\begin{array}{l}\text { Boccardia tricuspa } \\
\text { (Hartman, 1939) }\end{array}$} & \multirow[t]{5}{*}{ NIS } & Jhelius cirratus & Native & 6 \\
\hline & & Perumytilus purpuratus & Native & 6 \\
\hline & & Austromegabalanus psittacus & Native, \$ & 5 \\
\hline & & Lithothamnion sp. & Native & 1 \\
\hline & & Crepidula sp. & Native & 1 \\
\hline \multirow{3}{*}{$\begin{array}{l}\text { Dipolydora giardi } \\
\text { (Mesnil, 1896) }\end{array}$} & \multirow[t]{3}{*}{ NIS } & Argopecten purpuratus & Native*, \$ & 1 \\
\hline & & Ostrea chilensis & Native, $\$$ & 1 \\
\hline & & Crassostrea gigas & NIS, \$ & 1 \\
\hline \multirow{5}{*}{$\begin{array}{l}\text { Polydora bioccipitalis } \\
\text { Blake \& Woodwick, } 1971\end{array}$} & \multirow[t]{5}{*}{ NIS } & Mesodesma donacium & Native, \$ & 7,8 \\
\hline & & Mulinia edulis & Native, $\$$ & This study \\
\hline & & Crepidula fecunda & Native & 9 \\
\hline & & Crepidula sp. & Native & 1 \\
\hline & & Fissurella nigra & Native, $\$$ & 1 \\
\hline \multirow{4}{*}{$\begin{array}{l}\text { Polydora rickettsi } \\
\text { Woodwick, } 1961\end{array}$} & \multirow[t]{4}{*}{ NIS } & Argopecten purpuratus & Native*, \$ & 1,10 \\
\hline & & Ostrea chilensis & Native, $\$$ & 1 \\
\hline & & Crassostrea gigas & NIS, \$ & 1 \\
\hline & & Haliotis rufescens & NIS, \$ & 2 \\
\hline $\begin{array}{l}\text { Polydora uncinata } \\
\text { Sato-Okoshi, } 1998\end{array}$ & NIS & Haliotis discus hannai & NIS, \$ & 11 \\
\hline $\begin{array}{l}\text { Terebrasabella } \\
\text { heterouncinata } \\
\text { Fitzhugh \& Rouse, } 1999\end{array}$ & NIS & Haliotis rufescens & NIS, \$ & 12 , this study \\
\hline
\end{tabular}

1: Sato-Okoshi \& Takatsuka (2001); 2: Vargas et al. (2005); 3: Carrasco (1977); 4: Rozbaczylo \& Carrasco (1996); 5: Hernández et al. (2001); 6: Rozbaczylo et al. (1994); 7: Blake (1983); 8: Rozbaczylo et al. (1980); 9: Bertrán et al. (2005); 10: Basilio et al. (1995); 11: Radashevsky \& Olivares (2005); 12: Kuris \& Culver (1999)

* This species is considered to be "native to Chile", however within the country it has been trasplanted to culture facilities located outside of the native range 
et al. 2001, Hayes et al. 2005). Members of the family Spionidae were the most frequent boring polychaete species observed in Chile (one native and five introduced species). This finding coincides with reports from other aquaculture centers on the Pacific coast where Spionidae are the most frequently reported boring polychaete species (e.g. Eastern Pacific coast: USA, Baja California, México; Blake \& Evans 1973, Cáceres-Martínez \& Tinoco-Orta 2001, northwestern Pacific coast: Japan; SatoOkoshi 1999; and the southwestern Pacific coast: Australia; Lleonart et al. 2003a, 2003b, McDiarmid et al. 2004).

In Chile only three of the Spionidae species (Dipolydora huelma, Polydora rickettsi and $P$. uncinata) have been studied in terms of their effects on economically important introduced mollusc species (e.g. Haliotis spp.). All of these polychaetes have been found in landbased abalone aquaculture facilities. In southern Chile D. huelma and P. rickettsi are reported to infest Haliotis rufescens abalone farms. Infestation prevalence varies considerably according to the polychaete species (i.e. D. huelma has been reported to infest over $88 \%$ of mature abalone, while $P$. rickettsi infested approximately $24 \%$ of mature abalone), whether specimens are immature or mature (i.e. mature specimens are more infested) and locality (Vargas et al. 2005). In northern Chile $P$. uncinata had notably high levels of infestation prevalence, being found on up to $98.8 \%$ of medium to large sized Haliotis discus hannai (Radashevsky \& Olivares 2005). While these high prevalences of boring polychaetes in aquaculture facilities suggest important consequences for aquaculturists, none of these studies report on economic loss associated with polychaete infestations.

The two other families of boring polychaetes found in Chile were represented by fewer species (two species belonging to Cirratulidae and one species of Sabellidae). The two Cirratulidae species (Dodecaceria choromyticola and D. cf. opulens) were found infesting native and exotic hosts of economic importance on the Chilean coast. However, the economic effects of the infestation by Dodecaceria in culture centers on the Chilean coast are largely unknown, which is of concern especially considering that Dodecaceria is a reported pest in scallop cultures (Placopecten magellanicus) in New England (Blake 1969, Martin \& Britayev 1998). Furthermore, the discovery of one Sabellidae species (Terebrasabella heterouncinata) infesting red abalone (Haliotis rufescens) in Puerto Montt, southern Chile (Table 2) represents the first published record of this species in South America (R.A. Moreno, personal interview). This species has been widely documented as a marine pest in abalone culture centers in California, USA, where numerous studies have been conducted in attempts to control and/or eradicate this pest (Culver et al. 1997, Kuris \& Culver 1999, Culver \& Kuris 2000). Given the magnitude of damage caused by $T$. heterouncinata in aquaculture facilities on the northeastern Pacific coast, this polychaete constitutes a serious threat for aquaculture activities on the Chilean coast. At present this polychaete has only been observed in a closed circuit land-based culture system and all known hosts containing specimens were placed in quarantine and later eliminated (R.A. Moreno, personal interview).

\section{Affected host species}

The boring polychaete species utilized a total of 19 different host species, consisting in 15 mollusc species, three crustaceans and one calcareous encrusting alga. This listing included six native hosts with no commercial value, 10 native hosts with commercial value, and three NIS hosts introduced for aquaculture purposes (Table 1). We found evidence of native boring polychaete species infesting both native and non-indigenous hosts, as well as the contrary case of non-indigenous polychaetes infesting native and non-indigenous hosts. Three of the polychaete species presented host specificity: the non-indigenous polychaetes Polydora uncinata and Terebrasabella heterouncinata bored into introduced aquaculture species (i.e. Haliotis spp.), while the native Dodecaceria choromyticola infested economically important native molluscs. At present the two non-indigenous polychaetes are reported to present high host-specificity (Polydora uncinata and Terebrasabella heterouncinata), and are found only in landbased abalone aquaculture systems. Currently there is no available information regarding the potential introduction of this species to the 


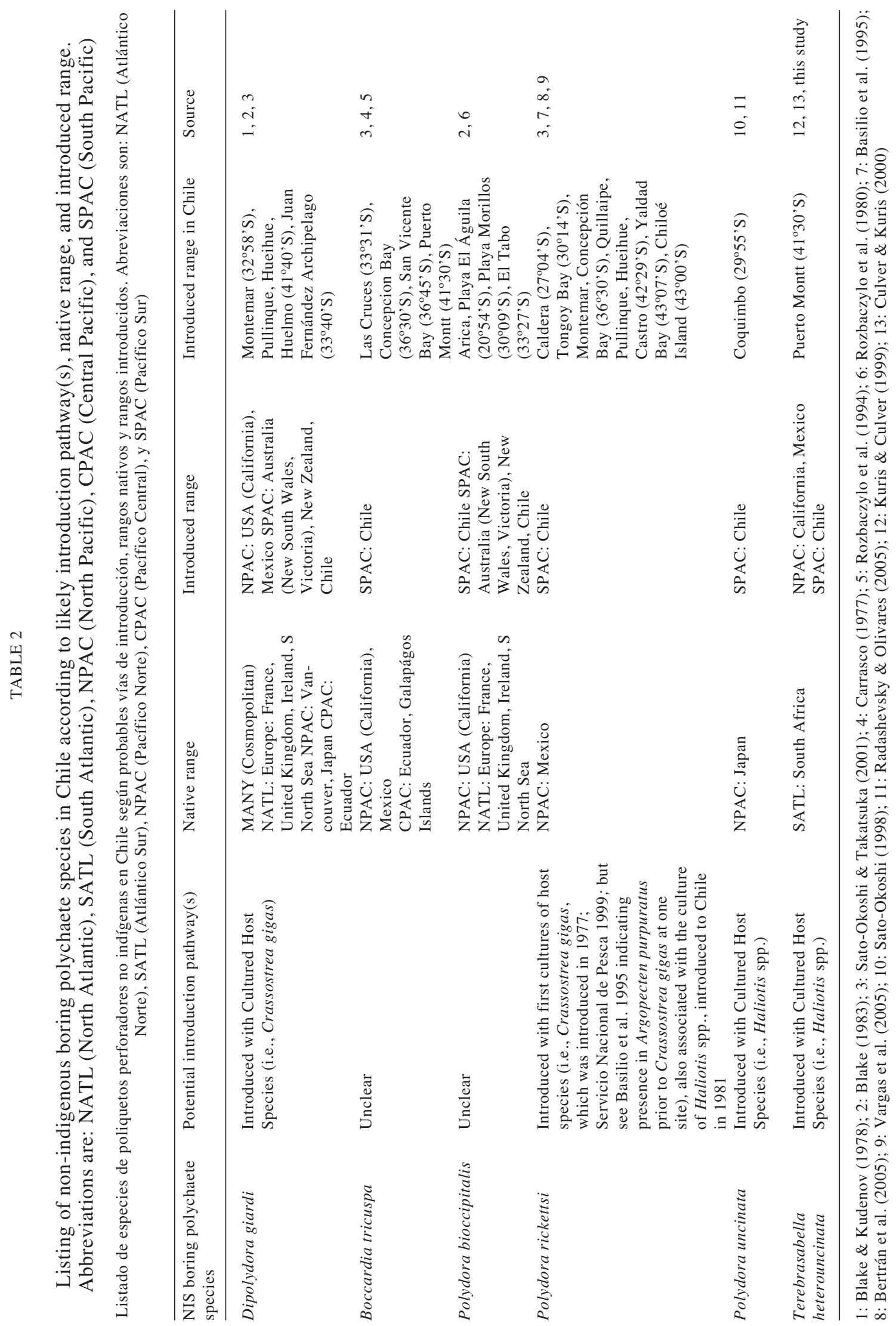


natural environment from the land-based systems (e.g. escape via effluent tubes). Furthermore, recent Chilean legislation now allows for the abalone hosts of these two species to be cultivated in open and semienclosed circuits in nearshore waters on the northern and southern coasts of Chile (FONDEF 1999, 2001, 2003, PYME 2005, see also discussion), which could constitute a potential risk to native host populations (Naylor et al. 2001). The other six species were observed to utilize multiple host species (Table $1)$. The finding that some native polychaetes also utilize introduced aquaculture species is cause for concern, since the high densities of available NIS hosts could support higher abundances of boring polychaete populations, which could subsequently increase the load of polychaetes on their native hosts. Likewise, the finding that several non-indigenous polychaetes utilize multiple hosts (including both native and introduced hosts) also constitutes a serious threat to native organisms which are affected by this load of new 'parasites' lacking a common evolutionary history (Sax \& Brown 2000).
Vectors and pathways of boring polychaete introductions to Chile

Aquaculture activities are likely the primary vector of introduction of exotic boring polychaetes to Chile (Table 2), probably involving long-distance transfers of polychaetes on molluscs from aquaculture facilities on other continents. This hypothesis is supported by the observations that four polychaete NIS are present in aquaculture centers and are reported to infest at least one exotic host species in Chile (Tables 1 and 2). For at least two polychaete species the data suggest that following their introduction with aquacultured species (e.g. Crassostrea gigas, Haliotis spp.) the polychaete taxa were able to disperse locally to nearby populations of native host species. These native hosts may promote further dispersal of the introduced polychaetes within the natural environment.

We identified a variety of possible donor areas, including the North Pacific Ocean (both east and west coasts), the Central Pacific (east coast), the South Pacific (east coast and west coast), the North Atlantic (east coast) and the

TABLE 3

Global geographical distribution of boring polychaete species recorded on the Chilean coast Distribución geográfica global de las especies de poliquetos perforadores registrados en la costa de Chile

Boring polychaete species Geographical distribution

Boccardia tricuspa (Hartman, 1939)

Dipolydora giardi (Mesnil, 1896)

Dipolydora huelma Sato-Okoshi \& Takatsuka, 2001

Dodecaceria choromyticola Carrasco, 1977

Dodecaceria cf. opulens Gravier, 1908

Polydora bioccipitalis Blake \& Woodwick, 1971

Polydora rickettsi Woodwick, 1961

Polydora uncinata Sato-Okoshi, 1998

Terebrasabella heterouncinata Fitzhugh \& Rouse, 1999
California, east coast of Mexico, Ecuador, Galapagos Islands (Hartman 1968, Blake 1983); Chile: Las Cruces (Rozbaczylo et al. 1994) to Puerto Montt (Sato-Okoshi \& Takatsuka 2001) Cosmopolitan on calcareous substrates (Sato-Okoshi \& Takatsuka 2001); Ecuador (Blake 1983); Chile: Montemar; Puerto Montt (Sato-Okoshi \& Takatsuka 2001), Juan Fernández Archipelago, Robinson Crusoe Island (Blake 1983) Chile: Seno Reloncaví (Sato-Okoshi \& Takatsuka 2001); Puerto Montt, Castro-Chiloé (Vargas et al. 2005)

Chile: Coliumo Bay (Carrasco 1977)

Perú; Chile: Península Hualpén, Concepción (Hernández et al. 2001); Puerto Montt

California; Chile: El Águila, a beach south of Iquique (Blake 1983); Santo Domingo, a beach south of the Port of San Antonio

Baja California, Mexico (Woodwick 1961); Chile: from Tongoy Bay (Basilio et al. 1995) to Chiloé (Vargas et al. 2005) Japan (Sato-Okoshi 1998); Chile: Coquimbo (Radashevsky \& Olivares 2005)

South Africa; California, Baja California, Mexico (Kuris \& Culver 1999); Chile: Puerto Montt 
South Atlantic (east coast). Five of the six NIS likely arrived from the northern hemisphere (Table 2). On the southeastern Pacific coast of Chile there was no clear pattern regarding areas of introduction. Non-indigenous polychaete species were observed in at least 20 different sites in northern, central and southern Chile, ranging from Arica $\left(20^{\circ} 54^{\prime} \mathrm{S}\right)$ to Yaldad Bay $\left(43^{\circ} 07^{\prime} \mathrm{S}\right)$ (Table 2$)$. The NIS polychaetes, $P$. uncinata and $T$. heterouncinata were recorded only in land-based aquaculture systems, while the native $D$. huelma was recorded in both land-based aquaculture systems and natural environments. The native Dodecaceria choromyticola was observed only in sea-based aquaculture systems and the NIS polychaetes $D$. giardi, and $P$. rickettsi were observed in both sea-based aquaculture systems and natural environments. Finally, two of the NIS, $B$. tricuspa and $P$. bioccipitalis, were recorded only in natural environments in the intertidal and shallow subtidal zones of the Chilean coast. The lack of a clear pattern in the introduced ranges of polychaete NIS within Chile may be a product of incomplete information regarding boring polychaete infestations on native hosts that are not of economic importance. Nevertheless, it is important to highlight that secondary pathways of dispersal from the source site may exist (e.g. the transfer of boring polychaetes on shellfish or aquaculture equipment moved between facilities). Evaluating potential vectors and introduction pathways of boring polychaetes is a fundamental part of the risk assessment process (e.g. Ruiz \& Carlton 2003).

CURRENT LAWS AND MANAGEMENT AND RECOMMENDATIONS FOR FUTURE MANAGEMENT

Legislation and management of boring polychaetes in Chile

It is important to highlight that although Chile has legislation regarding exotic species introductions to marine environments (The Fishery and Aquaculture Law, "Ley General de Pesca y Acuicultura" 1989), the main emphasis of these regulations has been on protecting the nation's natural resources. While written environmental law (Law 18.892) stipulates that aquaculturists must assure conditions that guarantee the protection of "biodiversity" (PYME 2005), in practice law-enforcers only effectively monitor effects on the "biodiversity" of native species of economic importance (e.g. Concholepas concholepas, Fissurella spp.).

Current legislation is focused on preventing the introduction and dispersal of non-target marine species associated with aquaculture activities (The Fishery and Aquaculture Law, "Ley General de Pesca y Acuicultura" 1989). For example, together with approving and financing projects to cultivate exotic abalone (Haliotis spp.) in sea cages along the Chilean coast, the government has also passed legislation which specifies that the abalone can only be farmed in areas devoid of hard substrates, and that concessions must strictly adhere to programs of environmental vigilance regarding the protection, control and eradication of "diseases" that present significant risks to hydrobiological species (Resolutions No 319/01 and 320/01 of Ministerio de Economía, Fomento y Reconstrucción, hereafter MEFR). However, many aquaculturists remain doubtful regarding whether it is possible to find adequate areas for aquaculture which comply with all of the measures of protection (e.g. areas devoid of hard substrates) (P.E. Neill, personal interview).

In addition, the government has provided funding to an institution (i.e. Fundación Chile) in charge of developing techniques for the prevention and control of infectious and noninfectious diseases in abalone, with specific reference to boring polychaetes (FONDEF 2001). Measures of polychaete prevention and control include quarantine of infested abalone, eradication of polychaetes via dessication, exposure to freshwater, chemicals or wax (R.A. Moreno, personal interview).

In 2003 the National Fisheries Service (Servicio Nacional de Pesca, hereafter SERNAPESCA) established the Active Vigilance Program ("Programa de Vigilancia Activa", Resolution No 1809/03) to monitor abalone and oyster aquaculture centers in Chile for high risk diseases. This monitoring program can also be extended to other aquaculture facilities and natural populations of economically important mollusc species if solicited. This program consists in semi-annual monitoring (fall and spring-summer) in and near aquaculture centers for the presence of 
specific high risk "diseases" in mollusc species. The monitoring is conducted by government authorized (SERNAPESCA) diagnostic laboratories who aim to identify sanitary risks associated with the aquacultured species as specified by a government ministry (i.e. MEFR), which dictates legislation on the Protection, Control and Eradication of High Risk Diseases to Hydrobiological Species (Resolution No 319/01). A subgroup of this ministry (Subsecretaria de Pesca) emits two lists of high risk disease organisms which should be evaluated (for more details see the Aquatic Animal Health Code, OIE 2005). Nevertheless, under current sanitary legislation (Resolution $\mathrm{N}^{\circ}$ 1623/05 MEFR), many polychaetes and other epi- or endo-bionts which are known to be present in aquaculture facilities are not considered "disease" agents, in spite of the damage that they cause to economically important mollusc species (e.g. "polydoriasis", Lleonart et al. 2003a, 2003b). At present SERNAPESCA is working to improve regulations to include the control of organisms that damage aquaculture facilities, but which have not yet been included on the high risk diseases lists (R.A. Moreno, personal interview).

The Chilean government has expressed its commitment to protecting native biodiversity by signing several international agreements (Camus 2005), including the International Convention on the Trade of Threatened Species of Wild Fauna and Flora (CITES, Supreme Decree No 141/75), which makes references to preventing the introduction of non-indigenous species that threaten ecosystems, habitats or species, and controlling or eradicating NIS which have been introduced. While in theory Chilean legislation aims to protect aquatic resources against unwanted invaders, such as non-indigenous boring polychaetes, whether or not these regulations are enforced or even feasible remains to be seen. The current socio-economic concerns of the country place strong pressure on law makers and enforcers which may hinder the application of measures to protect biodiversity in the field. For example, aquaculturists are currently lobbying to assuage proposed legislation to permit abalone farming in more marine areas (P.E. Neill, personal interview).

Worms settling onto and boring into shells cause myriad problems for aquaculturists (e.g. spoiled shell shape and quality, internal shell blisters, serious reduction in shell strength, damaged adductor muscles, energy wasted on shell repair, reduced flesh condition and increased vulnerability to serious pathogens, massive mortalities and resulting economic loss; Dunphy and Wells 2001, Lleonart et al. 2003a, 2003b, McDiarmid et al. 2004, Read 2004, Simon et al. 2004). Therefore, legislation to prevent, control and/or eradicate NIS polychaetes should provide long-term mutual benefits to both the nation's economy (e.g. aquaculture) as well as to the nation's native biodiversity. Nevertheless, social aspects of aquaculture in Chile, such as the need to obtain short-term profits-especially for small-scale aquaculturists-make the effective implementation of legislation and subsequent compliance with regulations a complex issue.

\section{Future recommendations}

Given the geographic layout of Chile (possessing over $4,200 \mathrm{~km}$ of coastline over 38 degrees of latitude, Camus 2001) this country has been touted as an ideal region for marine aquaculture; the same attribute, however, makes this region a prime target for nonindigenous species introductions. Given that exotic species introductions is a topic of global concern, and the fact that at least 6 NIS boring polychaete species are present on the Chilean coast, interacting with at least 14 native and non-indigenous hosts, it is important for researchers, managers and aquaculturists to develop strategies to prevent future introductions and to control or eradicate NIS that have already been introduced. Researchers need to generate baseline studies regarding the presence/absence of boring polychaetes in natural environments as well as determine the prevalence and ecological effects of nonindigenous polychaetes on their hosts.

A difficult task which must be broached in Chile is the need to develop a long-term plan which represents a rational compromise between the socio-economic plans for the country and plans to protect and preserve the nation's biodiversity (Arroyo 2003, Camus 2005). To ensure marine biosecurity in Chile it is fundamental to implement preventive measures, including periodic monitoring of native populations in the vicinity of both land- 
based and sea-based aquaculture facilities to detect and control the possible escape of nontarget species, implementation of treatment systems for water discharged from aquaculture facilities into the ocean (e.g. mechanical methods, electrochemical treatments, UV radiation, chlorine treatment) development of certification protocols to assess the cleanliness of introduced aquaculture species and aquaculture equipment and the establishment of active vigilance programs to assure that infested organisms and equipment are not moved between facilities within the country (see Campalans 2005). Researchers should develop a document for aquaculturists and the general public, which educates about the risks of non-indigenous species introductions and provides an efficient plan-of-action to follow whenever an NIS is discovered. In addition to penalties for organizations that do not comply with laws regarding species introductions, proactive legislation should also be implemented to restrict the arrival of NIS to Chile. Specific areas of focus should be identifying and controlling vectors of introduction and primary donor areas, and being alert to the arrival of species that are reported as pests in other regions of the world.

\section{ACKNOWLEDGEMENTS}

We thank Fernanda Oyarzún (University of Washington, Seattle, USA) for helping us with the literature on boring polychaetes from California, USA. We acknowledge the cooperation of Fabián Avilés (AquagestiónFundación Chile), Servicio Nacional de Pesca and Subsecretaría de Pesca, Valparaíso, Chile, and six anonymous experts who shared data and information in confidential interviews. The photographs of Terebrasabella heterouncinata and Dodecaceria cf. opulens were graciously provided by Fabián Avilés (AquagestiónFundación Chile). We are grateful to Dr. Patricio A. Camus and two anonymous reviewers for their valuable recommendations to improve this manuscript. Significant financial support was provided by Dr. Fabián Jaksic through FONDAP grant $\mathrm{N}^{\circ}$ 1501-0001 to CASEB (Cross-Cutting Tearn on Bioinvasions). R.A. Moreno is supported by the EU-project CENSOR "Climate variability and El Niño
Southern Oscillation: Impacts for natural resources and management", contract 511071 to the Alfred Weneger Institute for Polar and Marine Research (AWI), Bremerhaven, Germany. This is CENSOR publication 0024. P.E. Neill is supported by a CONICYT Doctoral Fellowship, CONICYT Thesis Project support (No AT-4040050), IDEA WILD grant and PEO Scholar Award.

\section{LITERATURE CITED}

ARROYO MK (2003) Biodiversidad y estudios de casos de especies exóticas: modelos actuales, predicciones futuras y recomendaciones generales. Centro Millenium de Estudios Avanzados en Ecología e Investigación en Biodiversidad, Universidad de Chile. 118 pp. http://www.derecho.uchile.cl/cda/documentos/ archivos/Biodiversidad $\% 20$ y $\% 20 \mathrm{Bioseguridad}$ $\% 20$ en $\% 20$ Chile.pdf

BASILIO CD, JI CAÑETE \& N ROZBACZYLO (1995) Polydora sp. (Spionidae), un poliqueto perforador de las valvas del ostión Argopecten purpuratus (Bivalvia: Pectinidae) en Bahía Tongoy, Chile. Revista de Biología Marina 30: 71-77.

BERTRÁN C, L VARGAS \& P QUIJÓN (2005) Infestation of Polydora rickettsi (Polychaeta: Spionidae) in shells of Crepidula fecunda (Mollusca: Calyptraeidae) in relation to intertidal exposure at Yaldad Bay, Chiloé, Chile. Scientia Marina 69: 99-103.

BLAKE JA (1969) Systematics and ecology of shellboring polychaetes from New England. American Zoologist 9: 813-820

BLAKE JA (1983) Polychaetes of the family Spionidae from South America, Antarctica, and adjacent seas and islands. Biology of the Antarctic Seas XIV. Antarctic Research Series 39: 205-288.

BLAKE JA \& KH WOODWICK (1971) New species of Polydora (Polychaeta: Spionidae) from the coast of California. Bulletin of the Southern California Academy of Sciences 70: 72-79.

BLAKE JA \& JW EVANS (1973) Polydora and related genera as borers in mollusk shells and other calcareous substrates. The Veliger 15: 235-249.

BLAKE JA \& JD KUDENOV (1978) The spionidae (Polychaeta) from southeastern Australia and adjacent areas with a revision of the genera. Memoirs of the National Museum of Victoria 39: 171-280

BOYD M, TJ MULLIGAN \& FJ SHAUGHNESSY (2002) Non-indigenous marine species of Humboldt Bay, California. Report to the California Department of Fish and Game, Arcata, California, USA. 118 pp. http://www.dfg.ca.gov/ospr/organizational/ scientific/exotic/Humboldt $\% 20$ Bay $\% 20$ Final $\% 20$ Report\%20Appendix \%20B_pdf

CÁCEREZ-MARTÍNEZ J., P MACÍAS-MONTES DE OCA \& R VÁSQUEZ-YEOMANS (1998) Polydora sp. infestation and health of the pacific oyster Crassostrea gigas in Baja California, NW México. Journal of Shellfish Research 17: 259-264

CÁCEREZ-MARTÍNEZ J \& G TINOCO-ORTA (2001) Symbionts of cultured red abalone Haliotis 
rufescens from Baja California, México. Journal of Shellfish Research 20: 875-881.

CAMPALANS M (2005) Bases científicas para el diseño de protocolos de traslado de recursos hidrobiológicos para evitar la dispersión de organismos constituyentes de plagas. Proyecto FIP 2005-16. http://www.fip.cl/

CAMUS PA (2001) Biogeografía marina de Chile continental. Revista Chilena de Historia Natural 74: 587-617.

CAMUS PA (2005) Introduction of species in Chilean marine environments: not only exotic, not always evident. Revista Chilena de Historia Natural 78: 155-159.

CÁRDENAS C \& JI CAÑETE (2004) Poliquetos polidóridos perforadores y su impacto en el cultivo de moluscos marinos en Chile. Austro Universitaria (Chile) 15: 52-63

CARRASCO FD (1977) Dodecaceria choromyticola sp. n . (Annelida, Polychaeta, Cirratulidae) perforador de Choromytilus chorus (Mytilidae). Boletín de la Sociedad de Biología de Concepción (Chile) 51: 6366.

CASTILLA JC, M URIBE, $\mathrm{N}$ BAHAMONDE, M CLARKE, R DESQUEYROUX-FAÚNDEZ, I KONG, H MOYANO, N ROZBACZYLO, B SANTELICES, C VALDOVINOS \& P ZAVALA (2005) Down under the southeastern Pacific: a survey of marine non-indigenous species in Chile. Biological Invasions 7: 213-232.

CASTILLA JC \& PE NEILL (IN PRESS) Marine Bioinvasions in the Southeastern Pacific: status, ecology, economic impacts, conservation and management. In: Rilov G \& J Crooks (eds) Marine bioinvasions: ecology, conservation, and management perspectives: Springer Verlag, Berlin, Germany.

CORRIERO G \& R PRONZATO (1987) Epibiontic sponges on the bivalve Pinna nobilis. Marine Ecology Progress Series 35: 75-82.

CRANFIELD HJ, DP GORDON, RC WILLAN, BA MARSHALL, CN BATERSHILL, MP FRANCIS, WA NELSON, CJ GLASBY \& GB READ (1998) Adventive marine species in New Zealand. NIWA Technical Report 34: 48 pp. http://www.niwa.co.nz/ rc/prog/marinebiodiversity/adventive.pdf

CULVER CS, AM KURIS \& B BEEDE (1997) Identification and management of exotic sabellid pests in California abalone aquaculture. California Sea Grant College Program. Publication $N^{\circ} \mathrm{T}-041$. $36 \mathrm{pp}$.

CULVER CS \& AM KURIS (2000) The apparent eradication of a locally established introduced marine pest. Biological Invasions 2: 245-253.

CULVER CS \& AM KURIS (2004) Susceptibility of California gastropods to an introduced South African sabellid polychaete, Terebrasabella heterouncinata. Invertebrate Biology 123: 316-323.

DUNPHY BJ \& RMG WELLS (2001) Endobiont infestation, shell strength and condition index in wild populations of New Zealand abalone, Haliotis iris. Marine Freshwater Research 52: 781-786.

EVANS JW (1969) Borers in the shell of the sea scallop, Placopecten magellanicus. American Zoologist 9: 775-782.

FAUCHALD K (1977) The Polychaete Worms. Definitions and Keys to the Orders, Families and Genera. Natural History Museum of Los Angeles County, Science Series (USA) 28: 1-190.

FITZHUGH K \& G ROUSE (1999) A remarkable new genus and species of fan worm (Polychaeta: Sabellidae: Sabellinae) associated with marine gastropods. Invertebrate Biology 118: 357-390.

FONDEF (1999) Cultivo suspendido del abalón japonés en el mar. Proyecto Fondo de Fomento al Desarrollo Científico y Tecnológico, Chile. http:// www.conicyt.cl/bases/fondef/PROYECTO/99/ I/ D99I1099.HTML

FONDEF (2001) Desarrollo de nuevas técnicas para la prevención y control de enfermedades infecciosas y no infecciosas en los cultivos de abalón. Proyecto Fondo de Fomento al Desarrollo Científico y Tecnológico, Chile. http://www.conicyt.cl/bases/ fondef/PROYECTO/01/I/DO1I1074.HTML

FONDEF (2003) Desarrollo tecnológico industrial del cultivo suspendido de abalón rojo Haliotis rufescens en el mar de sur de Chile. Proyecto Fondo de Fomento al Desarrollo Científico y Tecnológico, Chile. http://www.fondef.cl/bases/fondef/ PROYECTO/03/I/D03I1152.HTML

GIACOBBE S (2002) Epibiontic mollusc communities on Pinna nobilis L. (Bivalvia, Mollusca). Journal of Natural History 36: 1385-1396.

GRAVIER C (1908) Sur les Annélides polychètes rapportées par M. le Dr. Rivet de Payta (Përou). Bulletin du Museum de Histoire Naturelle Paris, 14: 40-44.

GROSHOLZ ED, GM RUIZ, CA DEAN, KA SHIRLEY, JL MARON \& PG CONNORS (2000) The impacts of a nonindigenous marine predator in a California bay. Ecology 81: 1206-1224.

HANDLEY SJ (2000) Larval development of Boccardia knoxi, a shell-infesting spionid polychaete. New Zealand Journal of Marine and Freshwater Research 34: 681-687.

HANDLEY SJ \& PR BERQUIST (1997) Spionid polychaete infestations of intertidal pacific oysters Crassostrea gigas (Thunberg), Mahurangi Harbour, northern New Zealand. Aquaculture 153: 191-205.

HARTMAN O (1968) Atlas of the Sedentariate Polychaetous Annelids from California. Los Angeles, Allan Hancock Foundation, University of Southern California, Los Angeles, California. 828 pp

HAYES K, C SLIWA, S MIGUS, F MCENNULTY \& P DUNSTAN (2005) National priority pest-Part II. Ranking of Australian marine pests. Department of Environment and Heritage by CSIRO Marine Research. http://www.marine.csiro.au/crimp// reports/PriorityPestsFinalreport.pdf

HERNÁNDEZ CE, G MUÑOZ \& N ROZBACZYLO (2001) Poliquetos asociados con Austromegabalanus psittacus (Molina, 1782) (Crustacea: Cirripedia) en Península Gualpén, Chile central: Biodiversidad y efecto del tamaño del sustrato biológico. Revista de Biología Marina y Oceanografía 36: 99-108.

KENT RML (1979) The influence of heavy infestations of Polydora ciliata on the flesh content of Mytilus edulis. Journal of the Marine Biological Association of the United Kingdom 59: 289-297.

KURIS AM \& CS CULVER (1999) An introduced sabellid polychaete pest infesting cultured abalones and its potential spread to other California gastropods. Invertebrate Biology 118: 391-403.

LLEONART M, J HANDLINGER \& M POWELL (2003a) Treatment of spionid mud worm (Boccardia knoxi Rainer) infestation of cultured abalone. Aquaculture 217: 1-10.

LLEONART M, J HANDLINGER \& M POWELL (2003b) 
Spionid mud worm infestation of farmed abalone (Haliotis spp.). Aquaculture 221: 85-96.

LÓPEZ DA, VA RIQUELME \& ML GONZÁLEZ (2000) The effects of epibionts and predators on the growth and mortality rates of Argopecten purpuratus cultures in southern Chile. Aquaculture International 8: 431-442.

MAGOULICK DD \& LC LEWIS (2002) Predation on exotic zebra mussels by native fishes: effects on predator and prey. Freshwater Biology 47: 19081918.

MARTIN D \& TA BRITAYEV (1998) Symbiotic polychaetes: review of known species. Oceanography and Marine Biology: an Annual Review 36: 217-340.

MCDIARMID H, R DAY \& R WILSON (2004) The ecology of polychaetes that infest abalone shells in Victoria, Australia. Journal of Shellfish Research 23: 1179-1188.

MCENNULTY FR, NJ BAX, B SCHAFFELKE \& ML CAMPBELL (2001) A review of rapid response options for the control of ABWMAC listed introduced marine pest species and relate taxa in Australian waters. Centre for Research on Introduced Marine Pests. CSIRO Marine Research Technical Report 23: 109 pp. http:// f t p.marin e.csiro.a / crimp/report s/ CRIMPTechReport23.pdf

NAYLOR RL, SL WILLIAMS \& DR STRONG (2001) Aquaculture-a gateway for exotic species. Science 294: 1655-1656.

OIE (2005) World Organisation for Animal Health: Aquatic animal health code. Web publication. http:/ /www.oie.int/eng/normes/fcode/en_sommaire.htm

ORENSANZ JM, E SCHWINDT, G PASTORINO, A BORTOLUS, G CASAS, G DARRIGRAN, R ELÍAS, J LÓPEZ GAPPA, S OBENAT, M PASCUAL, P PECHASZADEH, ML PIRIZ, F SCARABINO, ED SPIVAK \& EA VALLARINO (2002) No longer the pristine confines of the world ocean: a survey of exotic marine species in the southwestern Atlantic. Biological Invasions 4:115143.

PYME (2005) Subsecretaría de Pesca autoriza cultivos de abalones. Diario PYME (Chile) http:// www.diariopyme.cl

RADASHEVSKY VI \& C OLIVARES (2005) Polydora uncinata (Polychaeta: Spionidae) in Chile: an accidental transportation across the Pacific. Biological Invasions 7: 489-496.

READ GB (2004) Guide to New Zealand shell polychaetes. National Institute of Water and Atmospheric Research, New Zealand (NIWA). Web publication. http://biocollections.org/pub/worms/nz/ Polychaeta/ShellsPoly/NZShellsPolychaeta.htm

ROSS DJ, CR JOHNSON \& CL HEWITT (2003) Assessing the ecological impacts of an introduced seastar: the importance of multiple methods. Biological Invasions 5: 3-21.

ROZBACZYLO N, P SCHMIEDE \& M SÁNCHEZ (1980) Polydora sp. (Polychaeta, Spionidae) a parasite of the clam Mesodesma donacium (Mollusca, Mesodesmatidae). Archivos de Biología y Medicina Experimentales 13: 105

ROZBACZYLO N (1980) Clave para el reconocimiento de familias de Anélidos poliquetos del mar chileno. Studies on Neotropical Fauna and Environment 15: 167-196

ROZBACZYLO N (1985) Los Anélidos Poliquetos de Chile. Indice sinonímico y distribución geográfica de especies. Pontificia Universidad Católica de Chile, Serie Monografías Biológicas 3: 1-284.

ROZBACZYLO N, MA MÉNDEZ \& J BRAVO (1994) Presencia del poliqueto excavador Boccardia tricuspa (Hartman, 1939) (Polychaeta: Spionidae) en las valvas de Perumytilus purpuratus (Mollusca: Bivalvia). Gayana Oceanología (Chile) 2: 25-31.

ROZBACZYLO N \& FD CARRASCO (1996) Polychaete annelids associated to mollusc shellfish shells in the Chilean coast. Journal of Medical Applied Malacology 8: 98 .

RUIZ GM \& JT CARLTON (2003) Invasive Species Vectors and Management Strategies. Island Press, Washington, District of Columbia, USA. 518 pp.

SATO-OKOSHI W (1998) Three new species of polydorids (Polychaeta, Spionidae) from Japan. Species Diversity 3: 277-288.

SATO-OKOSHI W (1999) Polydorid species (Polychaeta: Spionidae) in Japan, with descriptions of morphology, ecology and burrow structure. I. Boring species. Journal of the Marine Biological Association of the United Kingdom 79: 831-848.

SATO-OKOSHI W \& M TAKATSUKA (2001) Polydora and related genera (Polychaeta: Spionidae) around Puerto Montt and Chiloé Island (Chile), with description of a new species of Dipolydora. Bulletin of Marine Science 68: 485-503.

SAX DF \& JH BROWN (2000) The paradox of invasion. Global Ecology and Biogeography 9: 363-371.

SERVICIO NACIONAL DE PESCA (1999) Anuario estadístico de pesca. Ministerio de Economía, Fomento y Reconstrucción, Chile. 291 pp.

SIMON C, H KAISER \& PJ BRITZ (2004) Infestation of the abalone, Haliotis midae, by the sabellid, Terebrasabella heterouncinata, under intensive culture conditions, and the influence of infestation on abalone growth. Aquaculture 232: 29-40.

VARGAS L, P QUIJÓN \& C BERTRÁN (2005) Polychaete infestation in cultured abalone (Haliotis rufescens Swainson) in southern Chile. Aquaculture Research 36: 721-724.

WOODWICK KH (1961) Polydora rickettsi, a new species of spionid polychaeten from lower California. Pacific Science 15: 78-81. 


\section{APPENDIX 1}

Questions asked during interviews of professional specialists in marine biosecurity in Chile with respect to legislation and the management of pests and high risk infectious diseases provoked by boring polychaetes in aquacultured species

Preguntas realizadas a profesionales especialistas en bioseguridad marina en Chile, en relación a legislación y el manejo de plagas y enfermedades infecciosas de alto riesgo provocadas por poliquetos perforadores en especies de cultivos

- How does Chile rank among developed countries such as Australia, New Zealand and the USA in terms of preventative measures regarding marine biosecurity?

- Are the governmental institutions that are in charge of legislating marine biosecurity issues, such as the National Fisheries Service (Servicio Nacional de Pesca; SERNAPESCA) and the Subsecretary of Fisheries (Subsecretaría de Pesca; SUBPESCA), currently working to develop and/or perfect new regulations such as the control and management of pests that cause economic damage to aquaculture businesses? What kind of monitoring programs are currently in existence?

- Are private aquaculture businesses along the Chilean coast developing plans to lobby the current legislation allowing an increase in the number of aquaculture centres for species of economic importance? Which particular issues are currently of concern to aquaculturists?

- Are the governmental entities in charge of protecting, controlling and eradicating high risk infectious diseases in aquaculture currently creating documentation and/or a plan of action to incorporate polydoriasis as a high risk disease in Chile?

- Do the specimens of red abalone (Haliotis rufescens) that were infested with the boring polychaete Terebrasabella heterouncinata come from reproductive stocks imported from aquaculture centers in California, USA?

- What sanitary procedure was followed for specimens of Haliotis rufescens infested with $T$. heterouncinata?

- Were the specimens of Haliotis rufescens infested with $T$. heterouncinata located in a closed, land-based culture system on in the sea?

\section{APPENDIX 2}

Profile of the professionals who were interviewed during our study. We indicate the professional title and/or academic degree, institutional affiliation and area of speciality regarding marine biosecurity in Chile

Perfil profesional de los encuestados donde se indica el título profesional y/o grado académico, afiliación institucional y áreas de especialización en materias de bioseguridad marina en Chile

\begin{tabular}{lll}
\hline Academic degree & Institution & Function \\
\hline Ph.D. in Biology & Subsecretary of Fisheries (SUBPESCA) & Biosecurity, laws \\
Veterinarian & National Fisheries Service (SERNAPESCA) & Pest management in aquaculture \\
Marine Biologist & Aqua-Gestión Fundación Chile & Pest management in aquaculture \\
Aquaculture Engineer & Private aquaculture business & Pest management in aquaculture \\
\hline
\end{tabular}




\section{APPENDIX 3}

Diagnosis of boring polychaete species recorded in this study infesting native and introduced mollusc hosts of economic importance on the Chilean coast

Diagnosis de las especies de poliquetos perforadores registradas en este estudio hospedando en moluscos nativos e introducidos de importancia económica en la costa de Chile

Terebrasabella heterouncinata Fitzhugh \& Rouse, 1999

Diagnosis: we examined the external morphology of a total of seven specimens, which were obtained by decalcifying shells of the red abalone, Haliotis rufescens Swainson, from Puerto Montt, Chile (Fig. 1). The presence of a skeleton in the branchial crown, fusion of the mid-dorsal margens of the branchial lobes and the presence of companion setae on the thoracic neuropodia indicate that the specimens belong to the subfamily Sabellinae (according to Fitzhugh \& Rouse 1999), within the family Sabellidae (according to keys by Fauchald 1977 and Rozbaczylo 1980). From the consistency in the observed characteristics for the seven specimens and the description by Fitzhugh \& Rouse (1999), we were able to identify all of the specimens as belonging to the species Terebrasabella heterouncinata. The specimens were 1-1.5 mm long. The branchial crown had two pairs of radioles. The anterior half of the body was thinner, and the posterior half was slightly expanded and sac-like (Fig. 2). Each individual had 8 thoracic segments and only three abdominal segments. Thoracic neuropodial uncini present in setigers 2-8 were of two types: those in setigers 2-6 were acicular, with a distinct main fang surmounted by a series of smaller teeth, while the uncini in setigers 7-8 were avicular, the main fang was absent and all teeth were uniform in size, in a narrow, elongate, rasp-shaped arrangement. Companion setae were present in the neuropods of setigers 2-6 and absent in setigers 7-8. Abdominal notopodial uncini in setigers 9-11 were acicular, with the distinct main fang surmounted by a series of smaller teeth.

Remarks: this species has been recorded living in galleries of the shells of various genera and species of marine gastropods in South Africa, including the abalone Haliotis midae, and in California there are records in the red abalone Haliotis rufescens.

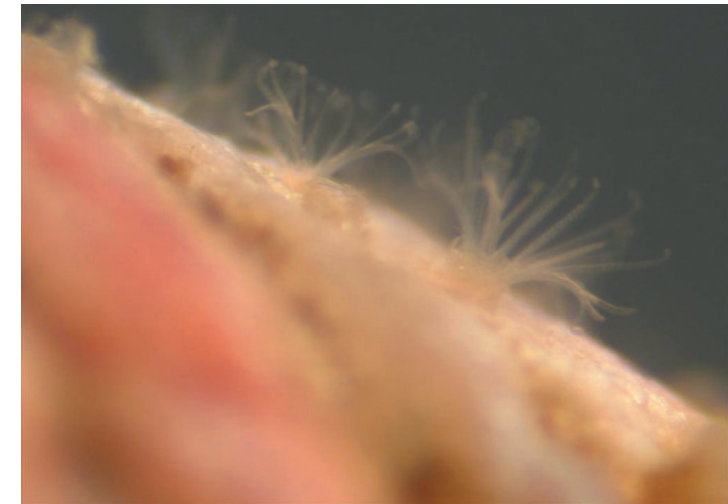

Fig. 1: Detail of the shell of a red abalone (Haliotis rufescens) from Puerto Montt, Chile, on which the branchial crowns of Terebrasabella heterouncinata can be observed (Photo: F. Avilés).

Detalle de una concha de abalón rojo Haliotis rufescens de Puerto Montt, Chile en que asoman las coronas branquiales de Terebrasabella heterouncinata (Foto: F. Avilés).

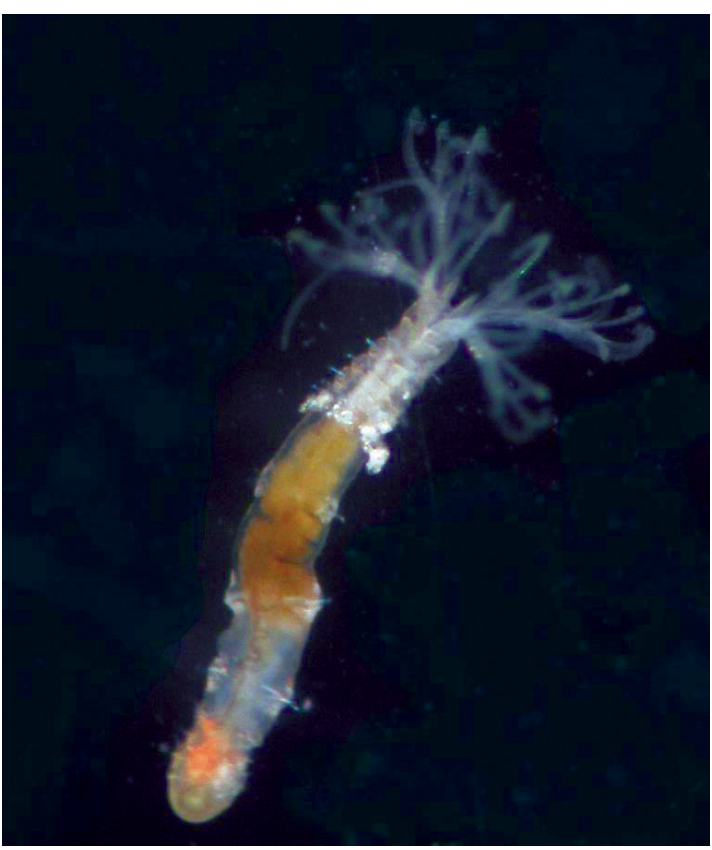

Fig. 2: Lateral view of a complete specimen of Terebrasabella heterouncinata which was extracted from a shell of the red abalone Haliotis rufescens from Puerto Montt, Chile (Photo: F. Avilés).

Vista lateral de un ejemplar completo de Terebrasabella heterouncinata extraído de una concha del abalón rojo $\mathrm{Ha}$ liotis rufescens de Puerto Montt, Chile (Foto: F. Avilés). 
Dodecaceria cf. opulens Gravier, 1908

Diagnosis: we examined the external morphology of three specimens extracted from galleries that were dug into the shell of the red abalone Haliotis rufescens (Fig. 3) from Puerto Montt, Chile. The color of the fixed specimens was brownish-orange and green; individuals measured between 30 to $60 \mathrm{~mm}$ in length and 2 $\mathrm{mm}$ wide, with up to 120 setigers (Fig. 4). The prostomium is blunt, and forms a hood over the mouth. The buccal segment is long and blunt, but with two stout grooved palps at its junction with setiger one. In the peristomium and second segment there are two pairs of branchial filaments; from the third to the eleventh segment there is only one pair of branchial filaments; with those of the first two segments being very short. The first setiger is uniramous with simple capillaries. The second setiger is biramous and bears notopodial and neuropodial setae. The setae of the first 10 setigers are simple capillaries with a serrated edge. Beginning at setiger 11 there are stout, notopodial and neuropodial spoon-shaped hooks. The neuropodial hooks are the most robust.

Remarks: in this study we record, for the first time, the presence of Dodecaceria cf. opulens in the shell of red abalone (Haliotis rufescens) from Puerto Montt, Chile. Earlier, Rozbaczylo \& Carrasco (1996) mention the presence of this species in the shells of the gastropod molluscs Fissurella maxima and Concholepas concholepas, as well as in the bivalve Aulacomya ater. Hernández et al. (2001) recorded this species in the shell of the barnacle Austromegabalanus psittacus in Concepción, Chile.

Polydora bioccipitalis Blake \& Woodwick, 1971

Diagnosis: we examined the external morphology of two specimens taken from a mud-blister in the shell of the clam Mulinia edulis (King \& Broderip). These specimens were compared with specimens extracted from the shell of Mesodesma donacium (Lamarck) that were deposited in the Collection of Flora and Fauna "Professor Patricio Sánchez Reyes" (SSUC), of the Pontificia Universidad Católica de Chile in Santiago. The specimens were 18 $\mathrm{mm}$ long, with up to 110 setigers. This species

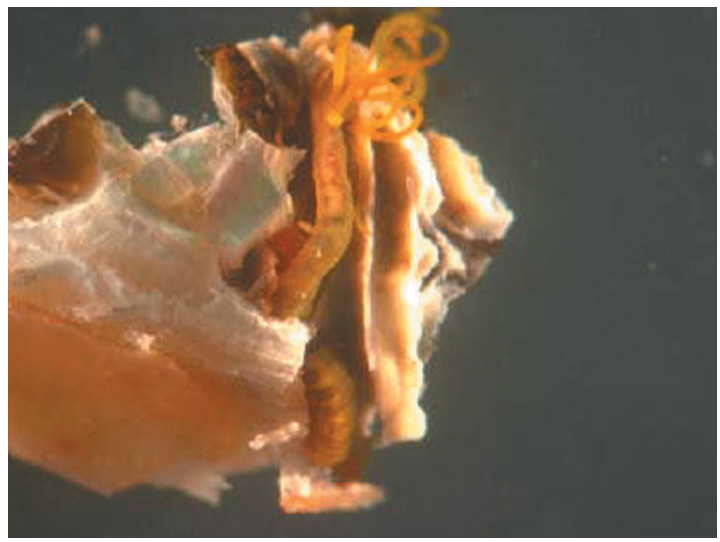

Fig. 3: A piece of shell from the red abalone Haliotis rufescens from Puerto Montt, Chile which has been bored into by a specimen of Dodecaceria cf. opulens (Photo: F. Avilés).

Trozo de concha de abalón rojo Haliotis rufescens de Puerto Montt, Chile perforado por un ejemplar de Dodecaceria cf. opulens (Foto: F. Avilés).

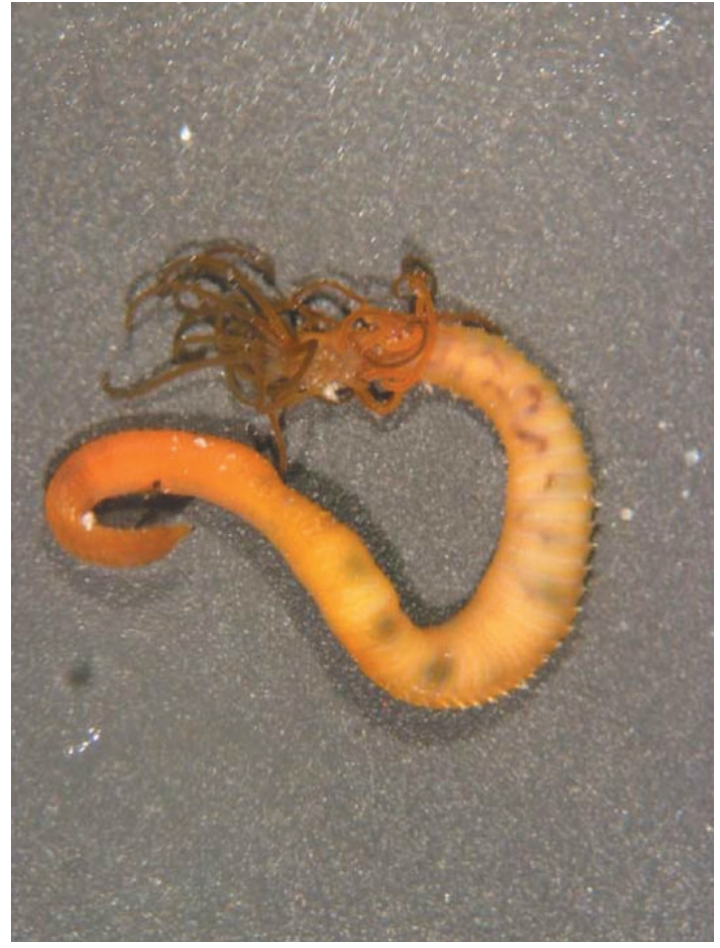

Fig. 4: Lateral view of a complete specimen of Dodecaceria cf. opulens extracted from a shell of the red abalone Haliotis rufescens from Puerto Montt, Chile (Photo: F. Avilés).

Vista lateral de un ejemplar completo de Dodecaceria cf. opulens extraído de una concha de abalón rojo Haliotis rufescens de Puerto Montt, Chile (Foto: F. Avilés). 
is easily recognized by the following combination of characters: the prostomium is deeply notched on the anterior margin, with a caruncle that extends up to setigers 10-14, approximately; with two nuchal tentacles in a row located at the level of the first setiger and between the palps, immediately following the two pairs of eyes. Notosetae are absent on setiger one. Bidentate hooded hooks are present on the neuropodia beginning at setiger 10. The branchiae are long, blunt and wide, and begin on setiger seven, continuing to near the posterior end of the body. Setiger 5 is larger than other setigers and includes a curved row of 8 to 10 heavy spines alternating with pennoned companion setae. The heavy spines are falcate and have three accessory structures. The pygidium is disclike, with a dorsal gap.

Remarks: in this study we recorded this species, for the first time, on the paleal sinus of a specimen of the clam Mulinia edulis (King \& Broderip), collected in the locality of Playa Santo Domingo, south of the port of San Antonio, Chile. Earlier, Rozbaczylo et al. (1980) recorded this species in the shell of live specimens of the bivalve Mesodesma donacium in Playa Morrillos. Blake (1983) recorded this species in Playa El Aguila, approximately 100 $\mathrm{km}$ south of Iquique, Chile in shells of live Mesodesma donacium. 